\title{
PENERAPAN MODEL PEMBELAJARAN INQUIRY TRAINING TERHADAP KETERAMPILAN BERPIKIR KRITIS
}

\author{
Lutfhi Nurrauf $^{\text {1), }}$, Ilah Nurlaelah ${ }^{2)}$, Ina Setiawati ${ }^{3)}$ \\ ${ }^{1}$ Mahasiswa Program Studi Pendidikan Biologi FKIP, Universitas Kuningan \\ Email : nurrauflutfhi@gmail.com \\ ${ }^{23}$ Dosen Program Studi Pendidikan Biologi FKIP, Universitas Kuningan \\ Email : ilah.nurlaelah@uniku.ac.id \\ Email : ina.setiawati@uniku.ac.id
}
APA Citation: Nurrauf, L., Nurlaelah, I., \& Setiawati, I. (2018). Penerapan Model Pembelajaran Inquiry Training Terhadap Keterampilan Berpikir Kritis. Quagga: Jurnal Pendidikan dan Biologi, 10(2), 33-38. doi: 10.25134/quagga.v10i2.1250.

Received: 08-06-2018

Accepted: $30-07-2018$

Published: 30-07-2018

\begin{abstract}
Abstrak: Rendahnya keterampilan berpikir kritis siswa pada kegiatan pembelajaran diakibatkan penggunaan model pembelajaran yang kurang tepat sehingga kurang merangsang siswa untuk meningkatkan keterampilan berpikir kritis. Tujuan penelitian ini untuk menganalisis pengaruh model pembelajaran inquiry training terhadap keterampilan berpikir kritis siswa pada materi sistem pertahanan tubuh di Kelas XI IPA SMA Negeri 1 Subang. Penelitian ini menggunakan metode eksperimen. Untuk memperoleh data, digunakan instrumen berupa tes uraian melalui Pretest dan Postest, serta menggunakan lembar observasi guru. Populasi penelitian ini seluruh siswa kelas XI SMA Negeri 1 Subang semester II tahun ajaran 2015/2016. Sampel yang digunakan 60 siswa, yakni sebanyak 31 siswa dari kelas XI IPA 1 sebagai kelompok eksperimen dan sebanyak 29 siswa dari kelas XI IPA 2 sebagai kelompok kontrol. Pengambilan sample dilakukan dengan teknik Cluster Random Sampling. Uji hipotesis menggunakan uji statistik parametrik, menggunakan uji $t$ independen untuk mengetahui pengaruh model pembelajaran inquiry training terhadap kemampuan berpikir kritis siswa. Dari analisis data dapat disimpulkan bahwa: terdapat perbedaan kemampuan berpikir kritis pada kelas eksperimen yang menggunakan model inquiry training dengan kelas kontrol yang menggunakan model pembelajaran konvensional. Hal ini didukung juga dengan hasil n-gain yang menyatakan adanya peningkatan kemampuan berpikir kritis pada kelas eksperimen sebesar 0.3 (sedang) dan kelas kontrol sebesar 0.1 (rendah). Maka model pembelajaran inquiry training berpengaruh terhadap keterampilan berpikir kritis siswa. Peningkatan tersebut dikarenakan pada setiap fase model inquiry training memfasilitasi siswa untuk berpikir kritis.
\end{abstract}

Kata Kunci : Model inquiry training, keterampilan berpikir kritis siswa

Abstract: The low critical thinking skills of students in learning activities are caused by the use of inaccurate learning models that are less stimulating for students to improve critical thinking skills. The purpose of this study was to analyze the effect of the inquiry learning training model on students' critical thinking skills in the body defense system material in Class XI Science of SMA 1 Subang. This research is using experimental method. To obtain data, the instrument was used in the form of a descriptive test through pretest and posttest, and using the teacher observation sheet. The population of this study were all students of class XI of SMA Negeri 1 Subang in the second semester of the 2015/2016 academic year. The sample used 60 students, namely as many as 31 students from class XI IPA 1 as the experimental group and as many as 29 students from class XI IPA 2 as the control group. Sampling is done by cluster random sampling technique. Hypothesis testing uses parametric statistical tests, using an independent $t$ test to determine the effect of inquiry training learning models on students' critical thinking abilities. From the data analysis it can be concluded that: there are differences in critical thinking skills in the experimental class using the inquiry training model with the control class that uses conventional learning models. This is also supported by the n-gain results which state an increase in critical thinking skills in the experimental class of 0.3 (medium) and the control class of 0.1 (low). Then the training inquiry learning model influences students' critical thinking skills. The increase is due to each phase of the inquiry training model facilitating students to think critically.

Keywords : inquiry training model, students' critical thinking skills

\section{PENDAhuluan}

Rendahnya keterampilan berpikir kritis siswa pada kegiatan pembelajaran diakibatkan penggunaan model pembelajaran yang kurang tepat sehingga kurang merangsang siswa untuk meningkatkan keterampilan berpikir kritis. 
Dalam proses pembelajaran, masih banyak siswa yang kurang aktif dalam mengungkapkan pertanyaan-pertanyaan, gagasan- gagasan, dan rasa keingintahuan mereka. Siswa terbiasa menerima ilmu secara langsung dari seorang guru atau cenderung pasif/satu arah.

Menurut Ennis dalam Fisher, A. (2009), menyatakan bahwa berpikir kritis adalah pemikiran yang masuk akal dan reflektif yang berfokus untuk memutuskan apa yang mesti dipercaya atau dilakukan. Keterampilan berpikir kritis yang dimiliki peserta didik, akan memacu semangat dalam menggali secara lebih dalam dan luas suatu ilmu pengetahuan. Untuk melatih dan menumbuhkan keterampilan berpikir kritis terhadap peserta didik, harus menggunakan cara belajar yang dapat menunjangnya, yaitu dengan menggunakan model pembelajaran yang tepat. Penerapan model pembelajaran inquiry training dapat menjadi solusi alternatif. Pembelajaran model inquiry training merupakan suatu model pembelajaran yang bertujuan membantu siswa mengembangkan disiplin intelektual dan keterampilan yang mumpuni untuk meningkatkan pertanyaan-pertanyaan dan pencarian jawaban yang terpendam dari rasa keingintahuan mereka (Joyce, dkk : 2009). Selain model inquiry training memfasilitasi siswa untuk melatih keterampilan berpikir kritis, model inquiry training juga dapat melatih siswa memperoleh ilmu yang berawal dari pemikirian/gagasan-gagasan siswa.

Proses pembelajaran menggunakan model inquiry training memfasilitasi siswa belajar lebih aktif dan lebih bermakna. Seperti hasil penelitian yang dilakukan oleh Septiana, Artika (2012) yang menyatakan hasil penelitiannya menunjukan bahwa model pembelajaran inquiry training dapat meningkatkan kemampuan berpikir kritis dan keterampilan proses sains siswa. Siswa mampu mencapai tujuan pembelajaran, tahapan inquiry training yang dianggap paling penting dalam melatih keterampilan berpikir kritis adalah kemampuan membuat hipotesis, kemampuan siswa dalam berhipotesis menghubungkan antara pengetahuan dan pengalaman siswa sehingga melatih siswa berpikir kritis dalam proses pembelajaran.

\section{METODOLOGI PENELITIAN}

Metode penelitian yang digunakan dalam penelitian ini adalah metode eksperimen, dengan desain True- Eksperimental. Desain TrueEksperimental yang digunakan yaitu PretestPostest Control Group Design. Dalam desain ini terdapat dua kelompok yang dipilih secara acak/random, kemudian diberi pretest untuk mengetahui keadaan awal dan postest untuk mengetahui keadaan akhir, sehingga diketahui adakah perbedaan antara kelompok eksperimen dan kelompok kontrol. Penelitian ini bertujuan untuk mengetahui pengaruh penerapan model pembelajaran Inquiry Training terhadap Keterampilan Berpikir Kritis siswa. Instrument yang digunakan dalam penelitian ini adalah tes essay untuk mengukur keterampilan berpikir kritis.

Pengambilan sample dilakukan dengan teknik Cluster Random Sampling. Uji hipotesis menggunakan uji statistik parametrik, menggunakan uji $t$ independen untuk mengetahui pengaruh model pembelajaran inquiry training terhadap kemampuan berpikir kritis siswa. Analisis data dalam penelitian ini menggunakan uji-t independent menggunakan Program Statistik (SPSS-17,0).

Untuk melihat peningkatan pada keterampilan berpikir digunakan perhitungan gain.

$$
<\text { gain }>=\frac{\text { skor post tes }- \text { skor pretes }}{\text { skor maksimum-skor pretes }}
$$

Hasil perhitungan gain diinterpretasikan menggunakan indeks gain $\langle\mathrm{g}\rangle$ menurut klasifikasi Meltzer (2002) sesuai dengan Tabel 1. di bawah ini.

Tabel 1. Kriteria Gain

\begin{tabular}{cc}
\hline Indeks & Interpretasi \\
Gain & Gain \\
\hline $\mathrm{g}>0,7$ & Tinggi \\
$0,3<\mathrm{g}>0,7$ & Sedang \\
$\mathrm{g} \leq 03$ & Rendah \\
\hline
\end{tabular}

\section{HASIL DAN PEMBAHASAN \\ Hasil}

Hasil uji-t independent nilai pretest untuk mengetahui pengaruh model pembelajaran inquiry training terhadap keterampilan berpikir kritis dilakukan dengan bantuan SPSS 16.0 for Window diperoleh nilai $\mathrm{F}$ hitung, Nilai sig. (P-Value) dan nilai $\mathrm{t}$ hitung seperti pada tabel 2 berikut: 
Quagga: Jurnal Pendidikan dan Biologi

Volume 10, Nomor 2, Juli 2018

Tabel 2. Hasil Perhitungan Uji t Independent Nilai Pretest Kelas Eksperimen Dan Kontrol Levene's Test for

\begin{tabular}{ccccc} 
& & \multicolumn{3}{c}{ Equality of Variances } \\
\cline { 3 - 5 } Pretest & $\begin{array}{c}\text { Equal } \\
\text { variances } \\
\text { assumed }\end{array}$ & 1.733 & Sig. & t \\
\hline
\end{tabular}

Berdasarkan tabel 2. nilai signifikansi lebih besar dari 0.05 ( $\mathrm{P}$ value >0.05) yakni $0,193>$ 0,05 maka terima $\mathrm{H} 0$ artinya bahwa tidak ada perbedaan rata-rata nilai pretest keterampilan berpikir kritis antara kelompok eksperimen dengan kelompok kontrol, dengan kata lain kedua kelas pada awal sebelum diberi perlakuan adalah sama (sepadan). Artinya berdasarkan hasil uji t pada hasil pretest kedua kelas tersebut di atas dinyatakan tidak memiliki perbedaan rata-rata yang signifikan sehingga kedua kelas dinyatakan sepadan. Adapun data hasil uji-t independen nilai postest untuk mengetahui pengaruh model pembelajaran inquiry training terhadap keterampilan berpikir kritis terdapat pada tabel 3 . berikut:

Tabel 3. Hasil Perhitungan Uji t Independent Nilai Postest Kelas Eksperimen Dan Kontrol

\begin{tabular}{ccccc}
\hline & & \multicolumn{3}{c}{$\begin{array}{c}\text { Levene's Test for } \\
\text { Equality of Variances }\end{array}$} \\
\cline { 3 - 5 } & $\mathrm{F}$ & Sig. & $\mathrm{t}$ \\
\hline Postest & $\begin{array}{c}\text { Equal } \\
\text { variances } \\
\text { assumed }\end{array}$ & 0.041 & 0.706 & 2.095 \\
& & & \\
\hline
\end{tabular}

Berdasarkan pada tabel 3. di atas diperoleh hasil perhitungan rata-rata keterampilan berpikir kritis postest kelas eksperimen dan kelas kontrol terlihat bahwa harga $t$ hitung untuk nilai postest keterampilan berpikir kritis dengan equal variances assumed (diasumsikan kedua varian sama) sebesar 2.095 dengan probabilitas 0,041 Oleh karena $\mathrm{P}$ value $=0,041<$ dari 0,05 maka Ho ditolak. Sedangkan berdasarkan t tabel dengan taraf kepercayaan 95\% $(\alpha=0,05)$ dan derajat kebebasan (df) 58 dengan uji 2 sisi menunjukkan harga 2.095 lebih kecil dari hasil perhitungan $t$ hitung dengan harga 2.095 atau t hitung $>t$ tabel $2.095>$ 2.002) maka Ho ditolak. Dengan ditolaknya Ho hal tersebut menunjukkan bahwa terdapat perbedaan rata- rata keterampilan berpikir kritis siswa yang signifikan antara kelas eksperimen dengan kelas kontrol. Dengan demikian dapat disimpulkan bahwa terdapat perbedaan keterampilan berpikir kritis akhir
p-ISSN 1907-3089, e-ISSN2651-5869

https://journal.uniku.ac.id/index.php/quagga

antara kelas eksperimen yang menggunakan model pembelajaran inquiry training dengan kelas kontrol yang menggunakan model pembelajaran konvensional. Hal tersebut didukung dengan hasil Perhitungan n-Gain, seperti pada tabel 4 berikut:

Tabel 4. Perhitungan n-Gain

\begin{tabular}{ccc}
\hline Kelas & Gain & Kategori \\
\hline Eksperimen & 0.3 & Sedang \\
Kontrol & 0.1 & Rendah \\
\hline
\end{tabular}

Dengan demikian dapat disimpulkan bahwa terdapat perbedaan keterampilan berpikir kritis siswa pada kelas eksperimen dengan kelas kontrol. Pada penelitian ini, soal tes keterampilan berpikir kritis yang digunakan yaitu sebanyak enam soal, dimana setiap dua soal menentukan satu indikator keterampilan berpikir kritis. Adapun rincian keberhasilan berpikir kritis siswa per-indikator antara kelas kontrol dan kelas eksperimen terdapat pada gambar 1 berikut:

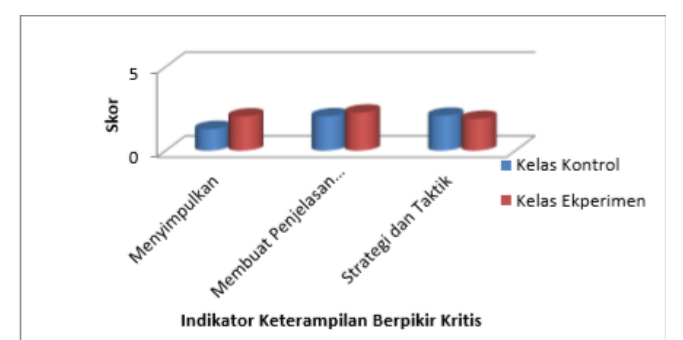

Gambar 1. Keberhasilan Keterampilan Berpikir Kritis Siswa per-Indikator

Berdasarkan gambar 1. di atas hasil perbandingan keberhasilan keterampilan berpikir kritis perindikator, terdapat hasil yang menunjukan kelas kontrol lebih baik daripada kelas eksperimen, yaitu pada indikator "Strategi dan Taktik (strategies and tactics)". Pada indikator "Strategi dan Taktik", skor rata-rata keberhasilan keterampilan berpikir kritis lebih 0,8 daripada kelompok eksperimen. Hal terebut dimungkinkan karena setiap siswa baik kelompok kontrol maupun kelompok eksperimen mempunyai kemampuan yang sama dalam membuat strategi dan taktik sebagai suatu langkah dalam mengatasi suatu permasalahan.

\section{Pembahasan}

Berdasarkan tabel hasil uji t untuk nilai postest didapatkan $\mathrm{t}$ hitung dengan harga 2.095 atau $\mathrm{t}$ hitung > t table $2.095>2.002$ ) maka Ho ditolak. Dengan ditolaknya $\mathrm{H}_{\mathrm{O}}$ hal tersebut menunjukkan bahwa terdapat perbedaan rata-rata keterampilan berpikir kritis siswa yang 
signifikan antara kelas eksperimen dengan kelas kontrol.

Perbedaan tingkat keberhasilan keterampilan berpikir kritis siswa apabila dilihat rata-rata skor per- indikator siswa pada tahapan "Menyimpulkan (Interference)" cukup jelas perbedaannya. Perbedaan tersebut membuktikan bahwa kemampuan siswa kelas eksperimen dalam membuat suatu kesimpulan cukup baik, hal tersebut karena tahapan-tahapan model inquiry training dapat merangsang siswa untuk berpikir kritis, sehingg dapat membuat suatu kesimpulan dengan tepat. Adapun tahapantahapan inquiry training yang melatih siswa membuat suatu kesimpulan yaitu seperti tahapan mengumpulkan serta memverifikasi data, mengumpulkan data dan eksperimentasi, serta mengolah dan merumuskan suatu penjelasan. Terkait dengan hasil keterampilan berpikir kritis yang menunjukan kelas kontrol lebih tinggi daripada kelas eksperimen, yaitu pada indikator "Strategi dan Taktik", hal tersebut dapat terjadi kaerna kemampuan siswa antara kelas kontrol dan eksperimen tidak jauh berbeda dalam membuat suatu strategi dan taktik dalam menyelesaikan suatu permasalahan. Namun, secara keseluruhan keberhasilan keterampilan berpikir kritis dengan menerapkan model inquiry training pada kelas eksperimen, dapat meningkatkan keterampilan berpikir kritis siswa lebih baik dibandingakan dengan kelas kontrol.

Berpengaruhnya model pembelajaran inquiry training terhadap keterampilan berpikir kritis pada diri siswa dalam mempelajari materi sistem pertahanan tubuh ditandai dengan meningkatnya rasa keingintauan siswa pada saat proses pembelajaran berlangsung. Hal ini sesuai dengan tujuan dari model pembelajaran inquiry training seperti yang dikemukakan oleh Joyce, dkk (2009) yang menyatakan bahwa "Tujuan utama model inquiry training adalah membantu siswa mengembangkan disiplin intelektual dan keterampilan yang mumpuni untuk meningkatkan pertanyaan-pertanyaan dan pencarian jawaban yang terpendam dari rasa keingintahuan mereka".

Berdasarkan kelas ternyata menunjukan ratarata keterampilan berpikir kritis dalam besaran yang berbeda. Besarnya rata-rata skor keterampilan berpikir kritis siswa pada kelas kontrol sebesar 60.93 dengan rata- rata skor keterampilan berpikir kritis siswa kelas eksperimen sebesar 68.58 dengan perbedaan skor 7.65. Peningkatan keterampilan berpikir kritis dengan perhitungan $\mathrm{g}$ faktor menunjukkan bahwa pada kelas control hanya mengalami kenaikan 0,1 berada pada katagori rendah, sedangkan pada kelas eksperimen mengalami kenaikan 0,3 berada pada katagori sedang. Hal ini menunjukkan bahwa penerapan model pembelajaran inquiry training memiliki pengaruh yang lebih tinggi terhadap keterampilan berpikir kritis siswa jika dibandingkan dengan pembelajaran dengan model konvensional. Hal ini berarti pembelajaran inquiry training dapat memfasilitasi siswa untuk melatih keterampilan berpikir kritisnya menjadi lebih baik.

Model inquiry training memfasilitasi kemampuan berpikir kritis siswa. Hal ini dapat dilihat dari tahapan atau fase pembelajarannya. Sebagai contoh pada fase 1 (siswa dihadapkan pada masalah), guru melontarkan permasalahan "mengapa pada musim pancaroba, banyak orang- orang yang terkena virus influenza? pada fase ini siswa akan membuat dan mempertimbangkan jawaban sesuai dengan tingkatan pengetahuan berpikirnya sehingga siswa dapat menyimpulkannya (interference) dengan benar. Fase 2 (mengumpulkan data), guru meminta siswa bertanya mengenai permasalahan yang sudah disampaikan. Pada fase ini siswa dituntut untuk mengetahui apakah suhu mempengaruhi siklus hidup virus influenza? Untuk mengetahui hal ini siswa akan mengumpulkan data-data dan memverifikasinya sehingga siswa dapat memberikan penjelasan lebih lanjut (advanced clarivication). Fase 3 (mengumpulkan data eksperimen), pada tahapan ini siswa akan mengumpulkan data eksperimentasi dengan cara memisahkan variabel-variabel yang relevan agar dapat menyusun jawaban berdasarkan hubungan sebab akibat. Pada fase ini siswa diarahkan memiliki keterampilan berpikir dalam mengidentifikasi asumsi (hipotesis) yang akan dibuat. Dengan demikian pada fase selanjutnya siswa akan belajar mengolah, dan merumuskan penjelasan. Di akhir fase siswa diharapkan terampil dalam membuat keputusan atau jawaban melalui strategi dan taktik (strategies and tactics) melalui analisa yang tepat.

Melalui penerapan model inquiry training, siswa dapat melatih keterampilan berpikir kritis dan belajar proses sains/kerja ilmiah seperti melatih keterampilan mengolah (mengobservasi, mengumpulkan dan mengolah 
data, mengolah data, mengidentifikasi dan mengontrol variabe-variabel, merumuskan dan menguji hipotesis dan penjelasan, menarik kesimpulan), melatih pembelajaran aktif (mandiri), pengungkapan verbal, toleran pada ambiguitas, berpikir logis, dan sikap bahwa semua pengetahuan bersifat tentatif, sehingga siswa dapat membangun suatu ilmu dari hasil pemikiran mereka melalui proses pembelajaran dengan menggunakan model pembelajaran inquiry training (Joyce, dkk:2009).

Penerapan model inquiri training memberi kesempatan siswa memiliki rasa ingin tahun yang tinggi, ketika rasa ingin tahu siswa semakin muncul dan secara aktif terlibat dalam proses perolehan informasi, maka akan membantu membangun pengetahuan mereka sendiri melalui proses berpikir. Hal inilah yang mendukung terjadinya peningkatan keterampilan berpikir berpikir kritis siswa (Apriyani, dkk; 2017).

Keberhasilan penerapan model inquiry training ini didukung juga oleh hasil lembar observasi. Berdasarkan hasil pengisian lembar observasi oleh guru pamong (dalam hal ini guru mata pelajaran Biologi), terlihat bahwa pembelajaran dengan menerapkan model pembelajaran inquiry training sudah sesuai dengan prosedur yang sudah ditetapkan. Keberhasilan penerapan model ini diantaranya karena siswa memberikan respon positif terhadap penerapan model pembelajaran inquiry training. Hal ini ditunjukan oleh keaktifan siswa pada saat pengumpulan data untuk menjawab permasalahan yang harus dipecahkan. Guru berpendapat bahwa model pembelajaran inquiry training memiliki keunggulan diantaranya: kegiatan belajar mengajar menjadi menarik, antusias belajar siswa cukup tinggi, siswa menjadi termotivasi untuk menyelesaikan permasalahan secara ilmiah, siswa terlatih menjadi peneliti- peneliti handal atau prosedur-prosedur penelitian ilmiah yang terstruktur.

Selain itu model pembelajaran inquiry training memberikan kesempatan pada siswa untuk mengaplikasikan pengetahuan yang mereka miliki dalam dunia nyata sehingga keterampilan berpikir kritis dapat berkembang secara maksimal, serta melatih siswa dalam belajar secara mandiri dan bertanggungjawab.

Berdasarkan hasil penelitian yang dilakukan oleh Rosiana (2015) yang berjudul pengaruh model pembelajaran inquiry training terhadap keterampilan berpikir kritis siswa pada konsep kalor, menyimpulkan bahwa terdapat pengaruh model pembelajaran inquiry training terhadap kemampuan berpikir kritis siswa pada konsep kalor. Menurutnya, berpengaruhnya model inquiry training terhadap keterampilan berpikir kritis tersebut disebabkan karena model pembelajaran inquiry training dibangun atas dasar dimana kesadaran siswa terhadap proses inkuiri ditingkatkan sehingga siswa dapat diajarkan prosedur pemecahan masalah secara ilmiah.

Berdasarkan hasil penelitian Septiana, Artika (2012) yang menyatakan hasil penelitiannya menunjukan bahwa model pembelajaran inquiry training dapat meningkatkan kemampuan berpikir kritis dan keterampilan proses sains siswa.

Adapun penelitian terkait model pembelajaran inquiry training, umumnya tentang model inkuiri adalah yang dilakukan Anggraeni, N. W. dkk (2013) yang menyatakan bahwa kemampuan berpikir kritis dan pemahaman konsep siswa melalui strategi pembelajaran inkuiri lebih unggul dibandingkan dengan stratgei pembelajaran langsung. Beberapa pernyataannya terkait model inkuiri diantaranya bahwa strategi pembelajaran inkuiri merupakan strategi pembelajaran yang dasar filosofinya konstruktivisme, karena melalui strategi ini siswa membangun sendiri pengetahuannya. Inkuiri memberikan siswa pengalaman-pengalaman belajar nyata dan aktif. Serta dengan model pembelajaran inkuiri siswa dilatih bagaimana memecahkan masalah, membuat keputusan, dan memperoleh keterampilan.

Berbagai keberhasilan penggunaan model inquiry training ini dapat dipahami karena karakteristik dari model inquiry training mampu merangsang peningkatan keterampilan dalam berpikir kritis. Selain model inquiry training mampu melatih siswa dalam proses kerja sains/ilmiah, model inquiry training juga dapat menciptakan suasana belajar yang menarik sehingga memacu semangat siswa dalam belajar. Tidak kalah pentingnya, bahwa dengan penerapan model pembelajaran inquiry training dapat memperkaya pemikiran dan membantu siswa belajar tentang ketidakmestian, memahami bahwa sifat pengetahuan yang selalu berkembang, siswa dapat menghargai penjelasan alternatif serta bertanggung jawab atas pemikiran atau gagasan mereka. 
Quagga: Jurnal Pendidikan dan Biologi

Volume 10, Nomor 2, Juli 2018

\section{SIMPULAN}

Berdasarkan hasil penelitian yang dilakukan, terdapat perbedaan kemampuan berpikir kritis pada kelas eksperimen yang menggunakan model inquiry training dengan kelas kontrol yang menggunakan model pembelajaran konvensional. Berdasarkan hasil uji $t$ didapatkan $\mathrm{t}$ hitung dengan harga 2.095 atau $\mathrm{t}$ hitung > t table $2.095>2.002$ maka Ho ditolak. Dengan ditolaknya $\mathrm{H}_{O}$ hal tersebut menunjukkan bahwa terdapat perbedaan rata-rata keterampilan berpikir kritis siswa yang signifikan antara kelas eksperimen dengan kelas kontrol.

\section{REFERENSI}

Anggraeni, N.W. et.al (2013). "Implementasi Strategi Pembelajaran Inkuiri Terhadap Kemampuan Berpikir Kritis dan Pemahaman Konsep IPA Siswa SMP”. E-journal Program Pasca Sarjana Universitas Pendidikan Ganesha. Singaraja.

http://www.undana.ac.id/jsmallfi b_top/. (diakses tanggal 13 Maret 2016).

Apriyani Lia, Nurlaelah Ilah dan Setiawati Ina. (2017). Penerapan Model PBL Untuk Meningkatkan Keterampilan Berpikir Kritis Ditinjau Dari Kemampuan Akademik Siswa Pada Materi Biologi. [Online]. Jurnal Quagga vol 9 No.1 Januari 2017, Tersedia :https://journal.uniku.ac.id/index.php/qu agga/article/view/509 (diakses tanggal 1 januari 2017)

Fisher, Alec. (2008). Critical Thinnking: An Introduction. Berpikir Kritis: Sebuah Pengantar. Terjemahan Benyamin Hadinata. Jakarta: Erlangga.

Joyce, Bruce. et.al. (2009). Models Of Teaching. Model-model Pengajaran. Terjemahan Achmad Fawaid dan Ateilla Mirza. Yogyakarta: Pustaka Pelajar

Meltzer, D.E. 2002. Relation between Student Problem-Solving Performance and Representation Format. American Journal of Physic. 73. No.5. P.465.

Rosiana. (2015). "Pengaruh Model Pembelajaran Inquiry Training
p-ISSN 1907-3089, e-ISSN2651-5869

https://journal.uniku.ac.id/index.php/quagga

terhadap Keterampilan Berpikir Kritis Siswa pada Konsep Kalor”. repository.uinjkt.ac.id/dspace/bit stream/123456789/.../ROSIANA-

FITK.pdf. (diakses tanggal 14 Agustus 2016)

Septiana, Artika. (2012). "Penerapan model pembelajaran inquiry training untuk meningkatkan kemampuan berpikir kritis dan keterampilan proses sains siswa kelas XI IPA 6 SMAN 3 Malang". http://library.um.ac.id/ptk/index. php? mod $=$ detail \&id=54429. $\quad$ (diakses tanggal 14 Agustus 2016). 